\title{
Article
}

\section{Antibacterial photodynamic inactivation of antibiotic-resistant bacteria and biofilms with nanomolar photosensitizer concentrations}

Carolina S Vinagreiro, Amanda Zangirolami, Fábio Antonio Schaberle, Sandra S.C.C. Nunes, Kate C Blanco, Natalia M. Inada, Gabriela J da Silva, Alberto C. C. Pais, Vanderlei S. Bagnato, Luis G. Arnaut, and Mariette Pereira

ACS Infect. Dis., Just Accepted Manuscript • DOI: 10.1021/acsinfecdis.9b00379 • Publication Date (Web): 08 Jan 2020

Downloaded from pubs.acs.org on January 10, 2020

\section{Just Accepted}

"Just Accepted" manuscripts have been peer-reviewed and accepted for publication. They are posted online prior to technical editing, formatting for publication and author proofing. The American Chemical Society provides "Just Accepted" as a service to the research community to expedite the dissemination of scientific material as soon as possible after acceptance. "Just Accepted" manuscripts appear in full in PDF format accompanied by an HTML abstract. "Just Accepted" manuscripts have been fully peer reviewed, but should not be considered the official version of record. They are citable by the Digital Object Identifier (DOI®). "Just Accepted" is an optional service offered to authors. Therefore, the "Just Accepted" Web site may not include all articles that will be published in the journal. After a manuscript is technically edited and formatted, it will be removed from the "Just Accepted" Web site and published as an ASAP article. Note that technical editing may introduce minor changes to the manuscript text and/or graphics which could affect content, and all legal disclaimers and ethical guidelines that apply to the journal pertain. ACS cannot be held responsible for errors or consequences arising from the use of information contained in these "Just Accepted" manuscripts. 


\title{
Antibacterial photodynamic inactivation of antibiotic- resistant bacteria and biofilms with nanomolar photosensitizer concentrations
}

\author{
Carolina S. Vinagreiro,$^{\dagger}$ Amanda Zangirolami, ${ }^{\star}$ Fabio A. Schaberle, ${ }^{\dagger}$ Sandra C. C. Nunes,${ }^{\dagger}$ Kate C. \\ Blanco, ${ }^{\ddagger}$ Natalia M. Inada, $₫$ Gabriela Jorge da Silva, ${ }^{\star}$ Alberto A. C. C. Pais, ${ }^{\dagger}$ Vanderlei S. Bagnato, ${ }^{\ddagger}$ \\ Luis G. Arnaut*,† and Mariette M. Pereira*,† \\ ${ }^{\dagger}$ Chemistry Department, University of Coimbra 3004-535 Coimbra, Portugal \\ \$São Carlos Institute of Physics, University of São Paulo, 13566-590, São Carlos, São Paulo, Brazil \\ \#Faculty of Pharmacy and Center for Neurosciences and Cell Biology, University of Coimbra, 3000- \\ 548 Coimbra, Portugal
}

\section{Corresponding Author information}

*E-mail: 1garnaut@qui.uc.pt

*E-mail: mmpereira@qui.uc.pt

Gram-negative bacteria and bacteria in biofilms are very difficult to eradicate and are at the origin of the most antibiotic-resistant bacteria. Therapeutic alternatives less susceptible to mechanisms of resistance are urgently needed to respond to an alarming increase of resistant nosocomial infections. Antibacterial photodynamic inactivation (PDI) generates oxidative stress that triggers multiple cell death mechanisms more difficult to counteract by bacteria. We explore PDI of multidrug-resistant bacterial strains collected from patients and show how positive charge distribution in the photosensitizer drug impacts on the efficacy of inactivation. We demonstrate the relevance of size for drug diffusion in biofilms. Designed meso-imidazolyl porphyrins of small size with positive charges surrounding the macrocycle enabled the inactivation of bacteria in biofilms by $6.9 \log$ units at $5 \mathrm{nM}$ photosensitizer concentration and $5 \mathrm{~J} \mathrm{~cm}^{-2}$, which offers new opportunities to treat biofilm infections.

KEYWORDS: photodynamic inactivation, multi-resistant bacteria, biofilms, porphyrinoids, antibiotics 
Antibiotic-resistant bacteria kill 50,000 people a year in Europe and in the USA, ${ }^{1}$ increase the total burden of nosocomial infections, ${ }^{2}$ and add risks to major surgeries, organ transplantation or treatment of preterm babies. We are witnessing what was described as an epidemic of resistant nosocomial infections. ${ }^{1}$ The major challenges to overcome are resistance originated by multidrug-resistant Gramnegative bacteria ${ }^{3}$ and by bacteria in biofilms. ${ }^{4}$ Carbapenem-resistant Acinetobacter baumannii infections treated with best available therapy lead to $50 \%$ mortality at 28 days $^{5}$ and carbapenem antibiotics are frequently the last line of defense against multidrug-resistant Gram-negative bacteria. Infections with ceftazimide-resistant Pseudomonas aeruginosa and Escherichia coli Gram-negative bacteria still show more favorable microbiological responses, ${ }^{6}$ but the options for treatment are decreasing. Bacterial infections involving bacterial biofilms are more difficult to eradicate because biofilms protect bacteria from hostile environments. Various mechanism contribute to the resistance of bacterial biofilms, namely decreased diffusion of biocides, deactivation of the antibacterial agent by outer layers of the biofilm, dormancy of the bacteria in some regions of the biofilm, and differentiation into a highly protected phenotypic state, in addition to conventional resistance mechanisms such as drug pumps. 4,7

Antibacterial photodynamic inactivation (PDI) is a promising alternative to antibiotic therapy because it involves a variety of cell death mechanisms and bacteria do not readily develop resistance to PDI. ${ }^{8}$ The photodynamic effect consists in the electronic excitation of a photosensitizer molecule that, in the excited state, transfers its excess energy to molecular oxygen (Type II process) or an electron to a neighboring molecule (Type I process). ${ }^{9}$ Type II processes generate singlet oxygen, whereas Type I processes lead to other reactive oxygen species (ROS) such as superoxide ion and hydroxyl radical. ${ }^{10-}$ ${ }^{11}$ PDI is mostly intended to treat infections in wounds and burns or in body cavities such as the mouth or the ear, and to treat surface infections of the cornea and skin. ${ }^{8}$ In such cases, the photosensitizers must have intense light absorption but not necessarily in the near infrared, where human tissues are more transparent, as opposed to the treatment of deep-seated lesions. A remarkable example of PDI is the use of $0.24 \mu \mathrm{M}$ of $\mathrm{Ga}$ (III)-protoporphyrin IX chloride, a hemin analog, to complete eradicate MSRA strains with high-affinity cell-surface hemin receptors. ${ }^{12}$ A more general approach to target bacteria is to employ polycationic antibiotics. It is known that they competitively displace the native divalent cations $\mathrm{Ca}^{+2}$ and $\mathrm{Mg}^{2+}$ that exert a stabilizing effect on the lipopolysaccharides of the outer membrane of Gram-negative bacteria, and disrupt this membrane. ${ }^{13}$ The increased membrane permeability then allows for more antibiotics uptake. This mechanism prompted the use of cationic 
photosensitizers in PDI of Gram-negative bacteria. ${ }^{14-16}$ PDI structure-activity studies with cationic photosensitizers, ${ }^{14,}{ }^{17-21}$ often derived from meso-tetra( $N$-methyl-4-pyridyl)porphyrin (TMPyP), led to photosensitizers that reduce colony-forming units (CFU) of bacteria by several log units at micromolar concentrations. ${ }^{22}$ For example, $1 \mu \mathrm{M}$ TMPyP was shown to reduce CFU of $E$. coli by $6 \log$ units. ${ }^{23}$ This efficacy is not unique to TMPyP derivatives: a similar success was reported with asymmetric dicationic bacteriochlorins monosubstituted at the 3-position. ${ }^{24}$

The role of Type I and Type II processes in PDI is not entirely clear. The lifetime of singlet oxygen $\left(\tau_{\Delta}\right)$ in cells and its associated diffusion length were recently established: $\tau_{\Delta} \approx 3 \mu \mathrm{s},{ }^{25}$ i.e. a diffusion length of $200 \mathrm{~nm}$ over a period of $5 \tau_{\Delta}$. This is also the membrane thickness of $S$. aureus. A photosensitizer localized in the cell wall may generate singlet oxygen that explores regions inside the bacterium. ${ }^{26}$ Photodamage of proteins in the membrane seems to suffice to trigger critical events that inactivate bacteria. ${ }^{27}$ Type I processes are responsible for PDI of E. coli and S. aureus using selfassembled $\mathrm{Zn}$-phthalocyanine derivatives with $50 \mathrm{~nm}$ diameters, ${ }^{28}$ probably too large to cross the cell envelope. We recently showed that imidazolium metallophthalocyanines do not need to be internalized by Gram-negative bacteria to show phototoxicity, at least when singlet oxygen is the predominant ROS. 29

This work describes the design, synthesis, characterization and use of photosensitizers to inactivate both Gram-positive and Gram-negative bacteria, including multidrug-resistant strains collected from patients, and bacteria in biofilms. The PDI photosensitizers were designed based on the following principles: (i) a chromophore with intense light absorption as basis, (ii) small size to facilitate uptake by bacteria and diffusion in biofilms, (iii) internal heavy-atom effect to generate long-lived triplet states with high quantum yields, ${ }^{30}$ (iv) resistance to oxidation to ensure high stability and favor singlet oxygen generation, ${ }^{11}$ (v) positive charge density exposed to displace native divalent cations from the outer layer of Gram-negative bacteria. Figure 1 presents some of the structures investigated, namely those involving $N$-methylpyridinium and 1,3-dimethylimidazolium substituents. At first sight, these substituents should impart very much the same properties to porphyrin templates. However, DFT calculations at the B3LYP/6-31G(d,p) level revealed that (1-methylimidazol-2-yl)porphyrins have a significantly higher positive charge density around the macrocycle than ( $N$-methyl-4pyridyl)porphyrins. Although cationic imidazolyl porphyrins are known, ${ }^{31-34}$ it seems that they were never used in PDI. We hypothesized that meso-imidazolyl porphyrins could interact strongly with Gram-negative bacteria walls and lead to efficient PDI of bacteria. We show that meso-imidazolyl 
porphyrins enabled $>5 \log$ units CFU decrease of multidrug-resistant Gram-negative bacteria at nanomolar concentrations under low light doses and that bacteria in biofilms can be eradicated with PDI.
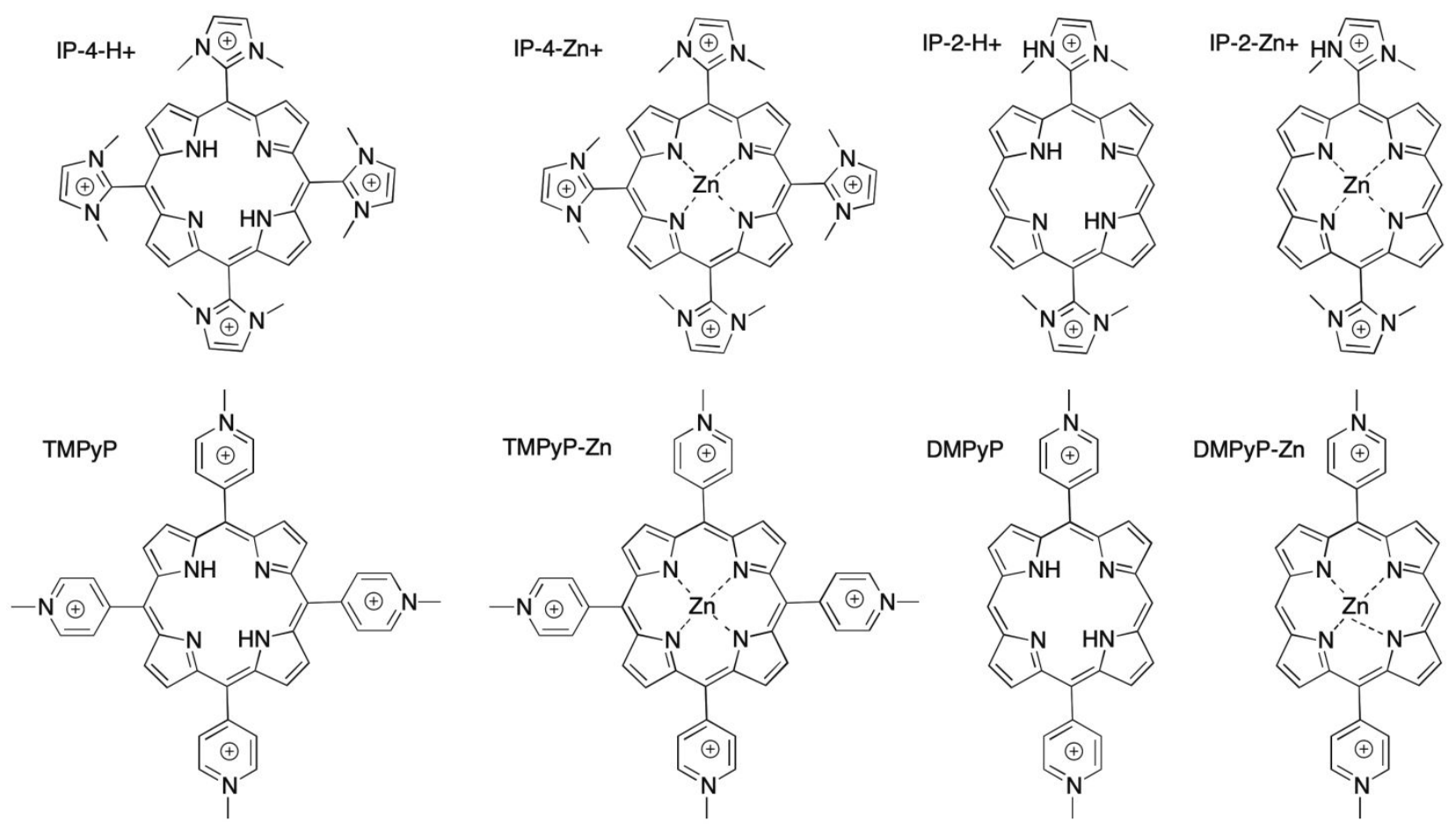

Figure 1. Molecular structures of cationic 1-methylimidazol-2-yl and $\mathrm{N}$-methyl-4-pyridyl porphyrins.

\section{RESULTS AND DISCUSSION}

Quantum chemical calculations were carried out to obtain insight regarding the distribution of positive charges on cationic photosensitizers and their preferred conformations. Figure 2 compares calculated positive charges densities using a color code where blue is a higher positive charge density and red is the lower positive charge. Additional calculations are presented in the Supporting Information (SI), including on 5,15-bis(3-methyloxazol-2-yl)porphyrinate zinc (II) and 5,15-bis(3-methylthiazol-2yl)porphyrinate zinc (II). It is clear that imidazolyl porphyrins have a considerable higher positive charge density than the corresponding $N$-methylpyridinium porphyrins of the same total charge. 3Methyloxazol-2-yl or 3-methylthiazol-2-yl substituents did not improve the positive charge density relative to imidazolyl porphyrins. Tetracationic imidazolyl photosensitizers have a higher charge density than the corresponding dicationic species, as expected, but both IP-4-Zn+ and IP-2-Zn+ were considered promising photosensitizers and their synthesis was pursued. 


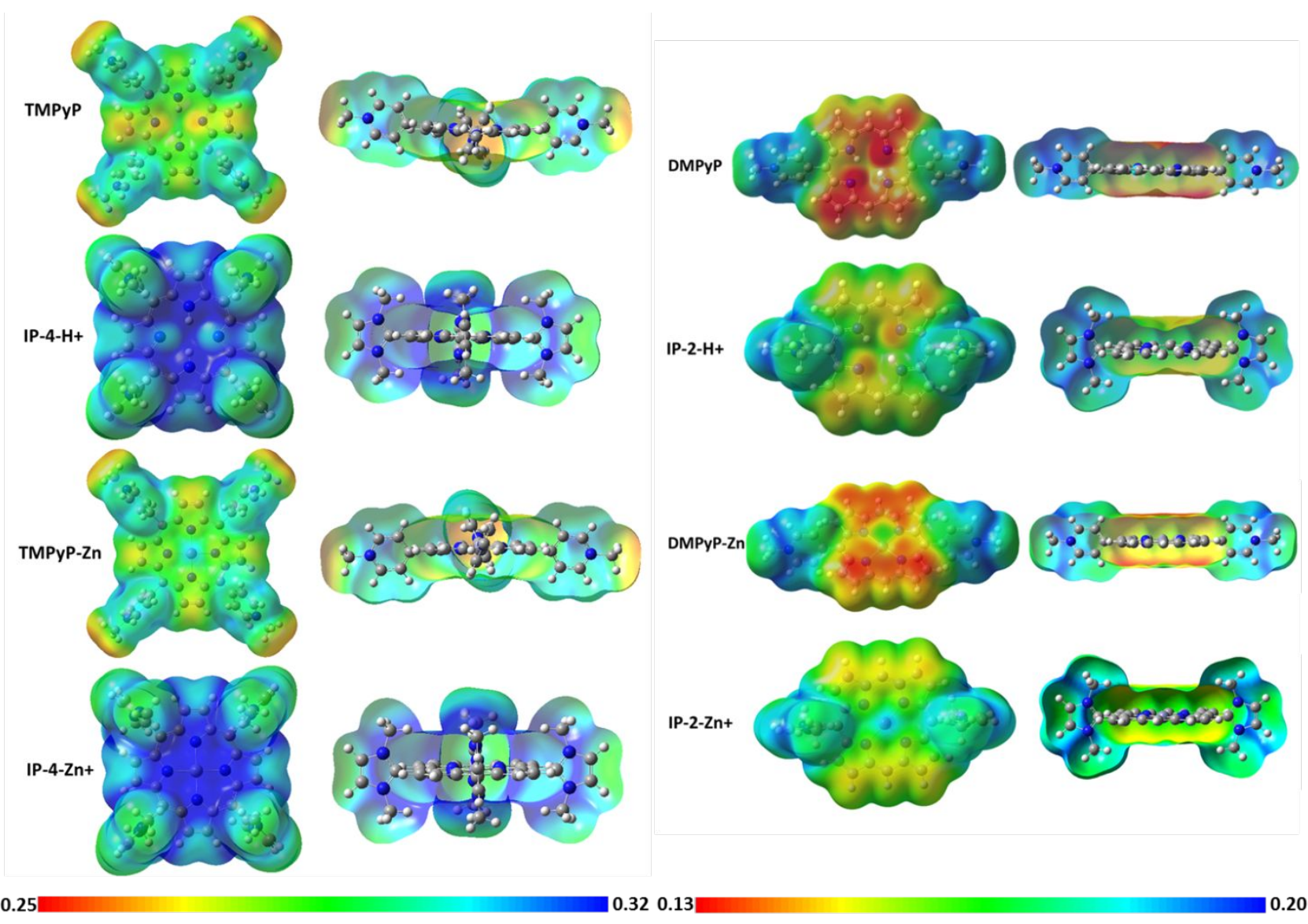

Figure 2. Electronic density maps of tetra- and di-cationic photosensitizers, without counterions, from total SCF density mapped with ESP, isovalue $=0.0004$ at $\mathrm{B} 3 \mathrm{LYP} / 6-31 \mathrm{G}(\mathrm{d}, \mathrm{p})$ level, in atomic units $\left(e / \mathrm{a}_{0}{ }^{3}\right)$.

The precursor 5,10,15,20-(1-methylimidazol-2-yl)porphyrin of IP-4-H+ and IP-4-Zn+ were synthesized using one-pot nitrobenzene method ${ }^{35}$ and 5,15-(1-methylimidazol-2-yl)porphyrin, precursor of IP-2-Zn+, was prepared by adaption of the two step MacDonald approach. ${ }^{36}$ Then, IP-4$\mathbf{H}+$ was prepared via quaternization of imidazole groups with a large excess of iodomethane, followed by metalation with an excess of $\mathrm{Zn}(\mathrm{OAc})_{2}$, yielding $92 \%$ of $\mathbf{I P - 4 - Z n +}$.

The imidazole group quaternization of IP-2-H was performed after the preparation of its zinc (II) complex, yielding IP-2-Zn+. The synthetic route for this photosensitizer is illustrated in Figure 3 and detailed procedures together with the characterization of the new compounds is described in Methods section. Table 1 gathers the most relevant properties of the studied photosensitizers. 

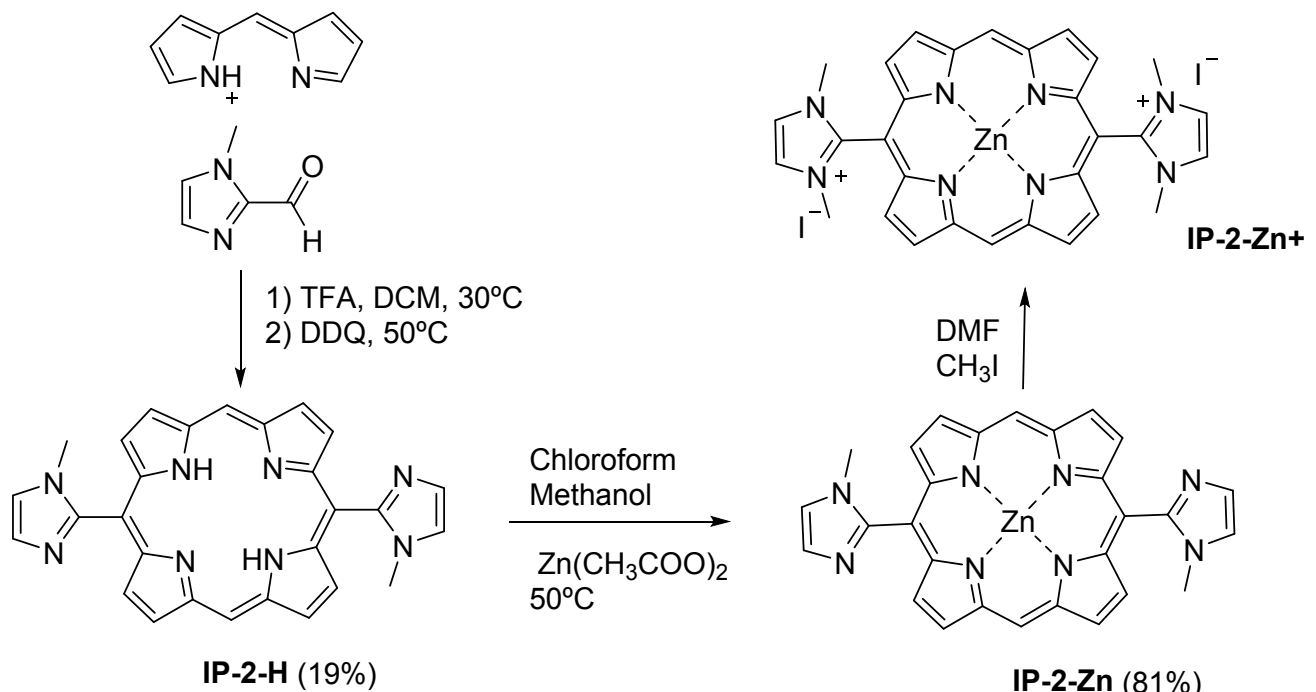

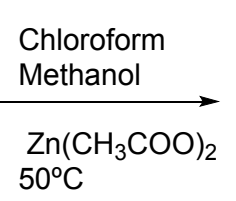
$50^{\circ} \mathrm{C}$

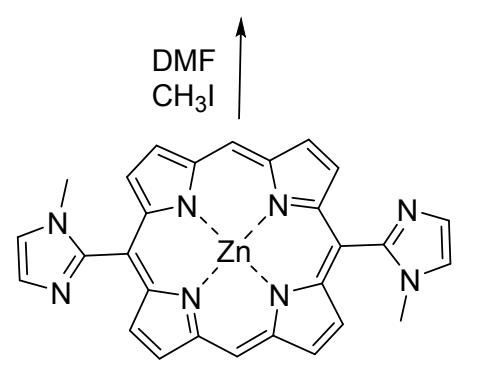

IP-2-Zn (81\%)

Figure 3. Preparation of IP-2-Zn+

Table 1. Properties of imidazolylporphyrins ${ }^{a}$

\begin{tabular}{|c|c|c|c|c|c|c|}
\hline Name & $\mathbf{M W} / \mathbf{D a}$ & $\begin{array}{c}\text { Soret absorption } / \mathbf{n m} \\
\left(\boldsymbol{\varepsilon} / \mathbf{M}^{-\mathbf{1}} \mathbf{c m}^{-\mathbf{1}}\right)\end{array}$ & $\boldsymbol{\Phi}_{\mathbf{F}}$ & $\boldsymbol{\Phi}_{\boldsymbol{\Delta}}$ & $\boldsymbol{\Phi}_{\mathbf{p d}}$ & $\log \boldsymbol{P}_{\mathbf{O W}}$ \\
\hline IP-4-H+ & 691 & $407\left(1.7 \times 10^{5}\right)$ & $0.14 \pm 0.04$ & $0.18 \pm 0.01$ & $4 \times 10^{-5}$ & - \\
\hline IP-4-Zn+ & 754 & $417\left(2.7 \times 10^{5}\right)$ & $0.13 \pm 0.03$ & $0.44 \pm 0.01$ & - & $1.81 \pm 0.41$ \\
\hline IP-2-Zn+ & 565 & $406\left(2.3 \times 10^{4}\right)$ & $0.10 \pm 0.02$ & $0.75 \pm 0.09$ & $8 \times 10^{-6}$ & $1.16 \pm 0.08$ \\
\hline
\end{tabular}

${ }^{a}$ In water as except for IP-2-Zn+ that required the addition of dimethylsulfoxide to $9 \% ; P_{\mathrm{OW}}$ represents the $n$-octanol:PBS (phosphate-buffered saline) partition coefficient.

The heavy-atom effect introduced by $\mathrm{Zn}^{2+}$ increased the singlet oxygen quantum yields $\left(\Phi_{\Delta}\right)$ mostly at the expense of internal conversion while leaving relevant fluorescence quantum yields $\left(\Phi_{\mathrm{F}}\right)$. IP-2$\mathbf{Z n}+$ achieves $\Phi_{\mathrm{F}}+\Phi_{\Delta}=0.85$ and leaves little room for processes other than Type II. The photostability, measured by the photodecomposition quantum yield $\left(\Phi_{\mathrm{pd}}\right)$, is high even when compared with that of TMPyP, which is considered very photostable. ${ }^{37}$

PDI of planktonic S. aureus ATCC 29213, E. coli ATCC 25922 and P. aeruginosa ATCC 27853 were evaluated after 60 minutes of incubation with 10,100 or $1000 \mathrm{nM}$ photosensitizer concentrations in the dark, followed by $8.33 \mathrm{~min}$ illumination with a $415 \mathrm{~nm} \mathrm{LED}\left(4 \mathrm{~mW} \mathrm{~cm}{ }^{-2}\right.$, i.e. $\left.1.36 \mathrm{~J} \mathrm{~cm}^{-2}\right)$. Figure 4 shows that $10 \mathrm{nM}$ IP-4-Zn+ reduces the survival fraction of both Gram-positive and Gram-negative 
bacteria by 4 to $5 \log$ units. This is significantly better than $\mathbf{I P - 4}-\mathbf{H}+$ and, in view of their similar electronic density maps, can be related to their difference in $\Phi_{\Delta}$. The bacteria were illuminated immediately after the incubation, without washing out the photosensitizer, because unbound photosensitizer molecules are expected to be present in PDI clinical applications of superficial infections. Figure 4 also shows that TMPyP, often used as a good example of a cationic photosensitizer, is not phototoxic to the bacteria under the same conditions. It should be noted that IP4-Zn+ and IP-2-Zn+ are not cytotoxic to HDFn neonatal human dermal fibroblast or HaCaT immortalized human keratinocyte human cells under conditions where they killed more than 4 log units of bacteria, as shown in Figure 5. The onset of phototoxic in these cell lines was only observed at 10 $\mu \mathrm{M}$ for $5 \mathrm{~J} \mathrm{~cm}^{-2}$.
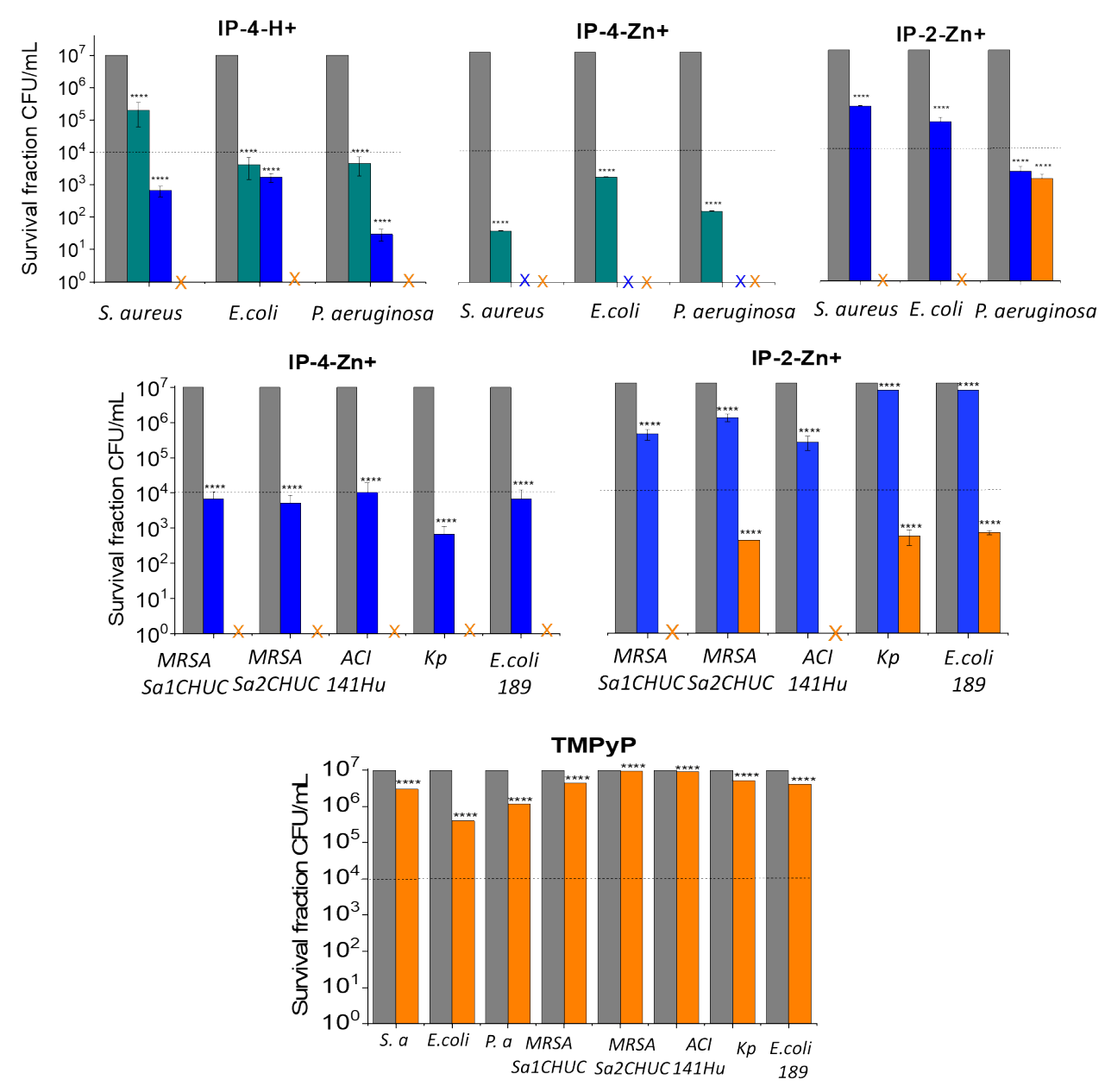

Figure 4. PDI in planktonic cultures of laboratory strains of bacteria (S. aureus ATCC 29213, E. coli ATCC 25922, P. aeruginosa ATCC 27853) and of clinical isolates of multidrug-resistant strains ( $S$. aureus Sa1CHUC and Sa2CHUC, A. baumannii 141HUC, $(A C I 141 H u)$ K. pneumonia $(K p)$, E. coli 
189) for various photosensitizer concentrations following $60 \mathrm{~min}$ incubation and a nominal light dose of $2 \mathrm{~J} \mathrm{~cm}^{-2}$ at $415 \mathrm{~nm}$ [ gray $0 \mathrm{nM}$; green $10 \mathrm{nM}$; blue $100 \mathrm{nM}$; orange $1000 \mathrm{nM}$ ]. The dashed black line shows viability values for $99.9 \%$ (3 log units) inactivation of microorganisms and the cross a total inactivation ( $7 \mathrm{log}$ units). The data expressed as mean value $(n=5) \pm \operatorname{sem}$. The label (****) represents statistically significant difference $(\mathrm{p}<0.0001)$.
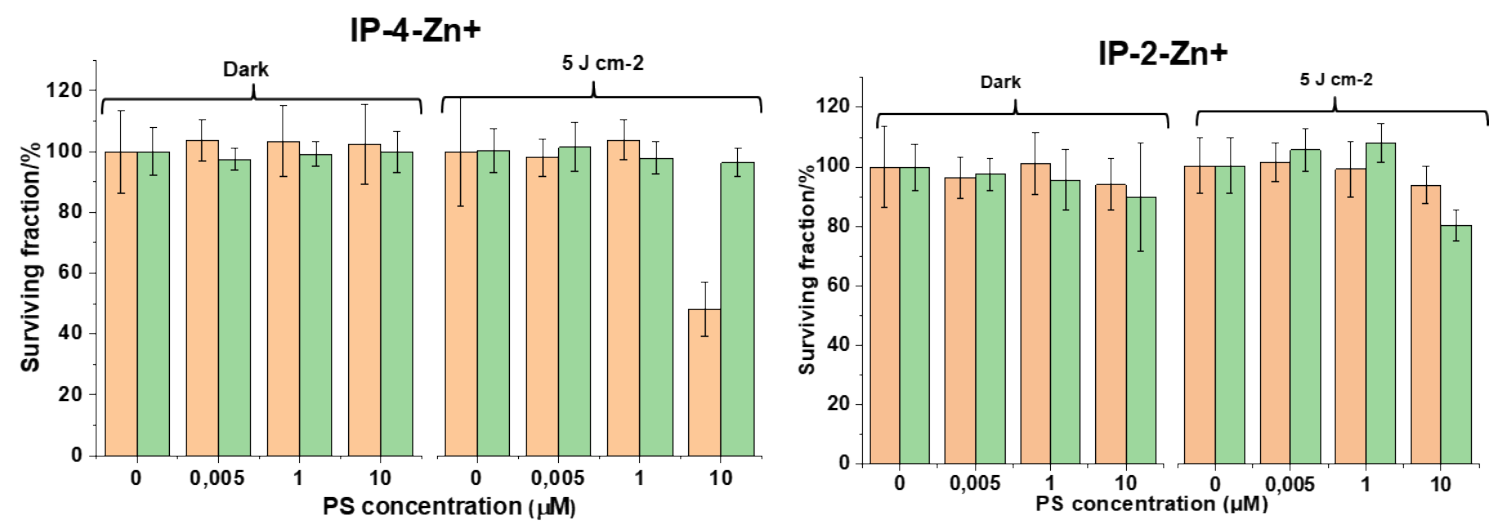

Figure 5. Cytotoxicity in the dark and phototoxicity with $5 \mathrm{~J} \mathrm{~cm}^{-2}$ of IP-4-Zn+ and IP-2-Zn+ towards $\mathrm{HDFn}$ dermal fibroblast (orange) or $\mathrm{HaCaT}$ keratinocytes (green). Data expressed as mean value ( $n=$ 6) \pm sem.

These encouraging results motivated PDI studies of multidrug-resistant bacterial strains collected at University of Coimbra Hospital Center (CHUC) with IP-4-Zn+ and IP-2-Zn+. The following bacteria strains were employed: S. aureus (MRSA Sa1CHUC) and A. baumannii 141HUC isolated from an exudate of a burn wound, S. aureus (MRSA Sa2CHUC) collected from an abdominal surgery infection, K. pneumoniae $(\mathrm{Kp})$ isolated from urinary tract infection and then from respiratory tract infection of a patient hospitalized in the Burn Unit, and E. coli 189 from a biological sample of farmed animal for food production. Figure 4 shows that sub-micromolar concentrations of IP-4-Zn+ with $1.36 \mathrm{~J} \mathrm{~cm}^{-2}$ reduced the surviving fraction of all these bacteria by $4-5 \log$ units. For this light dose and $1 \mu \mathrm{M}$, TMPyP only reduces that surviving fraction of $E$. coli for ca. $1 \log$ unit and is ineffective towards the inactivation of other bacteria. PDI studies reported in the literature usually employ higher light doses and micromolar concentrations to achieve 4-5 $\log$ units inactivations. ${ }^{22}$ We recently reported the eradication of Gram-negative bacteria with $100 \mathrm{nM}$ concentrations of a tetracationic imidazolium metallophthalocyanine, but the inactivation of Gram-positive bacteria required higher concentrations. ${ }^{38}$ 
The results obtained with IP-4-Zn+ and IP-2-Zn+ are quite remarkable and clinically relevant because MRSA is common in skin and mucosal infections, A. baumannii are opportunistic bacteria found in wounds and often in burn units, K. pneumoniae accounts for a significant proportion of hospitalacquired urinary tract infections, pneumonia, sepsis and soft tissue infections, and E. coli is an opportunistic pathogen that can infect any wound. The $K$. pneumoniae strain employed in our studies is considered extremely drug resistant (XDR). Although these strains are very difficult to treat, IP-4$\mathbf{Z n}+$ and IP-2-Zn+ remained very phototoxic at sub-micromolar concentrations.

Finally, recognizing that bacteria in biofilms can be 10-1000 times more resistant to antibacterial agents than planktonic bacteria, ${ }^{39}$ we investigated PDI of $S$. aureus ATCC 25925 biofilms using IP-4-Zn+ and IP-2-Zn+. We hypothesized that the smaller and less water-soluble photosensitizer, IP-2-Zn+, could partition better to the biofilm and diffuse in the biofilm without losing its phototoxicity potential. Biofilms were obtained after incubation of the bacteria in 24-well flat-bottom sterile polystyrene microplates for $24 \mathrm{~h}$ at $37^{\circ} \mathrm{C}$. After the establishment of the biofilms, they were incubated for 30-60 minutes in the dark at room temperature with the photosensitizers in the $5 \mathrm{nM}$ to $1 \mu \mathrm{M}$ concentration range, and then illuminated. Figure 6 shows that $5.2 \mathrm{nM}$ of IP-2-Zn+ with $5 \mathrm{~J} \mathrm{~cm}^{-2}$ decreased the fraction of surviving cells by 6.9 log units. While in planktonic bacteria IP-4-Zn+ is more effective than IP-2-Zn+, in biofilms their efficacies are reversed. The lower solubility of IP-2-Zn+ in water, its small size and large positive charge density combine to make this photosensitizer extremely powerful against biofilms. The importance of low charge and small size to succeed in PDI of biofilms was noted before, ${ }^{40}$ but in a study where a $100 \mu \mathrm{M}$ concentration of a monocationic small photosensitizer was necessary to achieve essentially the same as with $5.3 \mathrm{nM}$ of IP-2-Zn+. The potency of antibiotics can be reported in minimum bactericidal concentrations (MBC). This is not entirely adequate for photosensitizers because lower drug concentrations can be partly compensated by higher light doses, and the incubation times relevant for photosensitizers (less than $1 \mathrm{~h}$ ) and for antibiotics (18 to $24 \mathrm{~h}$ ) are widely different. Nevertheless, in order to provide a comparative value, $5.3 \mathrm{nM}$ of IP-2-Zn+ kills 7 $\log$ units of CFU, which is more than required for MBC, and corresponds to $0.003 \mathrm{mg} / \mathrm{L}$. Hence, it can be considered that $5.3 \mathrm{nM}$ of IP-2-Zn+ corresponds to $\mathrm{MBC}<0.003 \mathrm{mg} / \mathrm{L}$. Under a light dose of $5 \mathrm{~J}$ $\mathrm{cm}^{-2}, \mathbf{I P - 2 - Z n}+$ becomes at least as potent as the most potent antibiotics. ${ }^{41}$ 


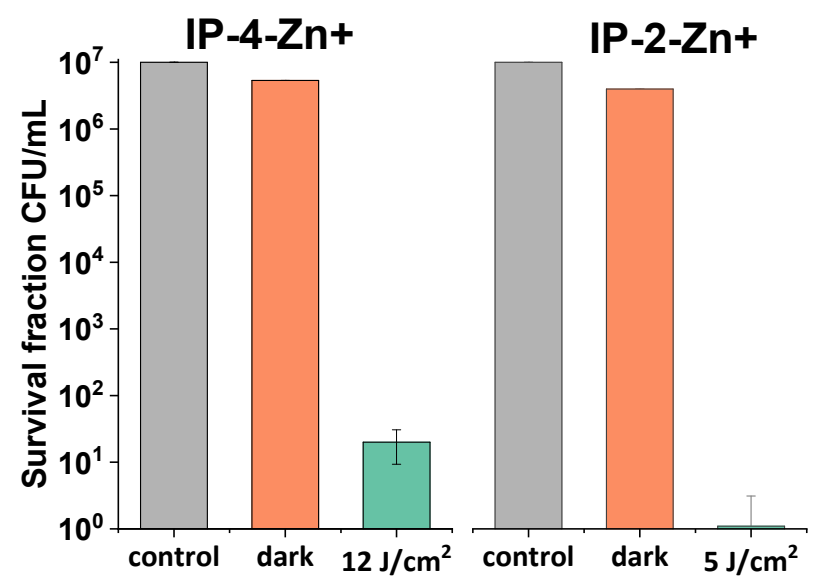

Figure 6. PDI of $S$. aureus biofilms using 400-650 nm LED light with a fluence rate of $30 \mathrm{~mW} \mathrm{~cm}^{-2}$ $(1 \mu \mathrm{M}$ of IP-4-Zn+; $5.2 \mathrm{nM}$ of IP-2-Zn+). Data expressed as mean value $(n=6) \pm$ sem.

In order to obtain further insight into the interaction of our photosensitizers with biofilms, we used confocal microscopy to observe biofilms incubated with IP-2-Zn+, IP-4-Zn+ or TMPyP. The SI presents videos of biofilms incubated with IP-2-Zn+ and IP-4-Zn+. Figure 7 shows the images after incubation for $60 \mathrm{~min}(\mathbf{I P - 4 - Z n +}$ and TMPyP) or $30 \mathrm{~min}(\mathbf{I P - 2}-\mathbf{Z n}+)$. The auto-fluorescence of the bacteria is shown in green and the fluorescence of the photosensitizers is overlaid in red. The presence of the biofilms can be observed as "islands" of different green tonality in a "sea" of planktonic bacteria. The fluorescence of IP-4-Zn+ comes essentially from the planktonic bacteria. TMPyP seem to be in solution and also in the margins of the biofilms. In contrast, the fluorescence of IP-2-Zn+ comes from the inside of the biofilm. These images clearly demonstrate that the exceptional PDI activity of IP-2$\mathbf{Z n}+$ can be attributed to its rapid penetration in the biofilm structure. 
A

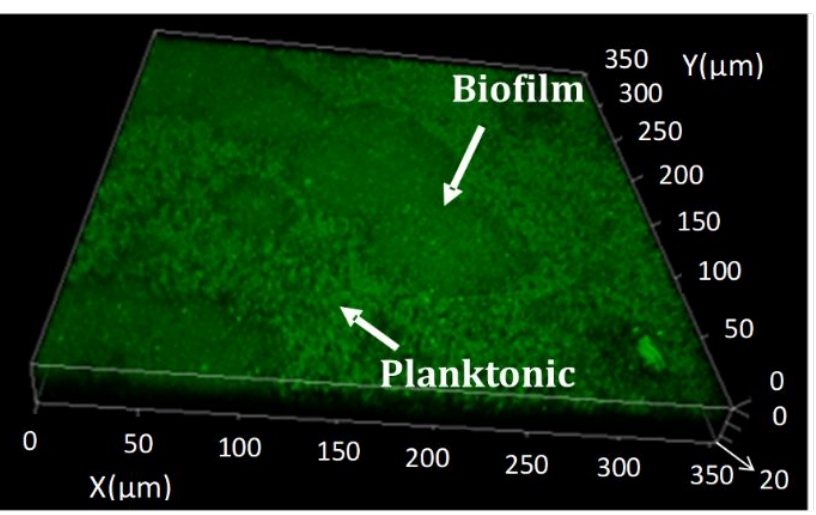

C

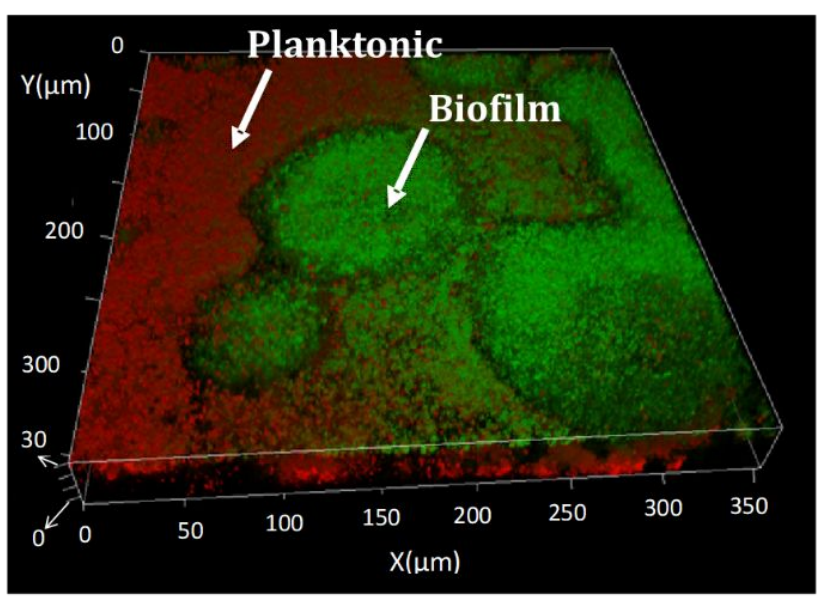

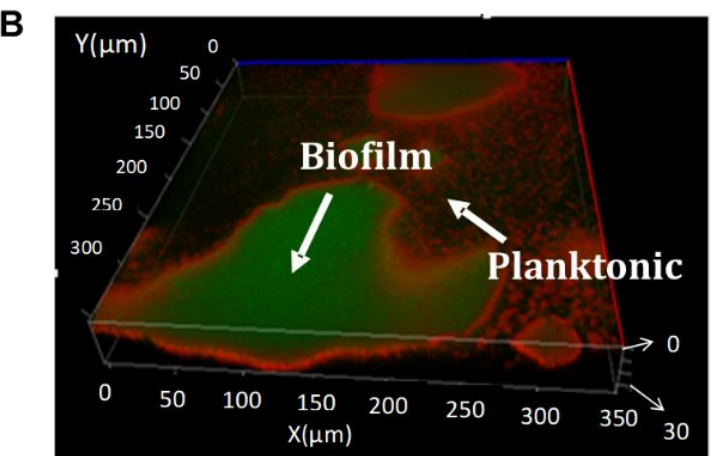

D

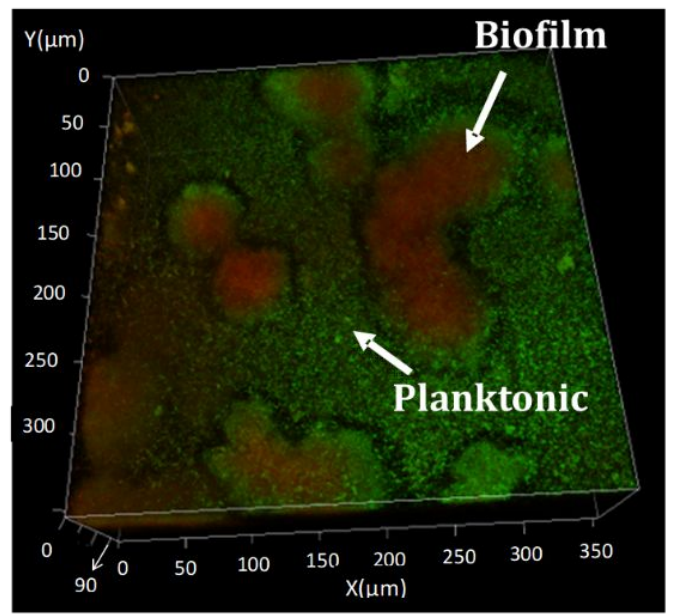

Figure 7. Confocal microscopy of S. aureus biofilms. (A) Autofluorescence of bacteria (green). (B) Fluorescence after incubation with $1 \mu \mathrm{M}$ of TMPyP. (C) Fluorescence after incubation with $1 \mu \mathrm{M}$ of IP-4-Zn+. (D) Fluorescence after incubation with $1 \mu \mathrm{M}$ of and IP-2-Zn+.

\section{CONCLUSIONS}

Zn (II) imidazolyl porphyrins designed to enhance positive charge around the macrocycle enabled a reduction by $5 \log$ units of the surviving fraction of both naïve and antibiotic-resistant strains of Grampositive and Gram-negative bacteria at nanomolar photosensitizer concentrations. The four positive charges of IP-4-Zn+ are likely to be involved in very strong electrostatic interactions with biofilm components such as negatively charged extracellular polymeric substances. These interactions together with its relatively large size limit the efficacy of IP-4-Zn+ in the eradication of bacteria biofilms. IP$\mathbf{2 - Z n}+$ overcomes these challenges. Bacteria present in biofilms were eradicated using $5.2 \mathrm{nM}$ of IP$\mathbf{2 - Z n +}$. The lower water solubility and the high $\Phi_{\Delta}$ of IP-2-Zn+ also contribute to its success. PDI of bacteria biofilms with IP-2-Zn+ is not limited by diffusion, deactivation in the biofilm, dormancy of 
the bacteria or phenotypic differentiation. $\mathrm{Zn}(\mathrm{II})$ complexes of (1,3-dimethylimidazol-2yl)porphyrinates open new opportunities for PDI of antibiotic-resistant bacteria and biofilms.

\section{MATERIAL AND METHODS}

Calculations. Molecular structures were optimized at the DFT level of theory, using the B3LYP hybrid functional ${ }^{42-44}$ and the standard $6-31 \mathrm{G}(\mathrm{d}, \mathrm{p})$ basis set. Calculations were performed combining the capabilities of Gaussian $09^{45}$ and Gamess ${ }^{46}$ program packages. Gamess was used for geometry optimization while HOMO-LUMO, volume, and electron density maps were calculated with Gaussian. Solvent accessible and excluded surface areas were determined using UCSF Chimera version 1.13.147 with the help of the MSMS package. ${ }^{48}$ The molar volumes $\left(V_{\mathrm{M}}\right)$ and solvent excluded surface areas (SE) obtained with these calculations are not expected to have a precision better than 10\% (see SI).

General methods. Standard methods are described in the SI, including computational details and analytical methods.

Synthesis. IP-4-Zn+ was synthesized according to some modifications of the nitrobenzene methodology, 35,49 followed by quaternization of imidazolyl groups and subsequently complexation with $\mathrm{Zn}$. The characterization is in agreement with the literature (see SI). ${ }^{33}$

5,15-Bis(1,3-dimethylimidazol-2-yl)porphyrinate zinc (II) diiodide, (IP-2-H). A solution of commercial dipyrromethene (438 mg, $3 \mathrm{mmol}$ ) and 1-methylimidazole-2-carboxaldehyde (330 $\mathrm{mg}, 3$ mmol) in $\mathrm{CH}_{2} \mathrm{Cl}_{2}(300 \mathrm{ml})$ was degassed with a continuous stream of argon, for $10 \mathrm{~min}$, before addition of catalytic amounts of TFA $(153 \mu \mathrm{L}, 2 \mathrm{mmol})$. The reaction vessel was shielded from ambient light and stirred under argon, along 3 hours, at $\mathrm{T}=25^{\circ} \mathrm{C}$. Then, 3-dichloro-5,6-dicyano-1,4-benzoquinone (DDQ) (2.04 g, $6 \mathrm{mmol}$ ) was added, at once, to the reaction mixture, and stirring was pursued for 1 hour. After removal of the solvent, the crude was dissolved in $\mathrm{CH}_{2} \mathrm{Cl}_{2}$ and washed with a saturated solution of sodium bicarbonate. After that, a silica gel column chromatography was performed, using dichloromethane/methanol (10:1) as eluent. After solvent evaporation, 5,15-bis(1-methylimidazol-2yl)porphyrin IP-2-H was isolated and, after drying under vacuum, the desired non-symmetric porphyrin IP-2-H was obtained with $19 \%$ yield $(134 \mathrm{mg}) .{ }^{1} \mathrm{H} \mathrm{NMR}\left(400 \mathrm{MHz}, \mathrm{CDCl}_{3}, 25^{\circ} \mathrm{C}\right): \delta$ mixture of atropoisomers (ppm) $10.35(\mathrm{~s}, 2 \mathrm{H}), 9.43(\mathrm{~d}, J=4.3 \mathrm{~Hz}, 4 \mathrm{H}), 9.03$ (d, $J=4.3 \mathrm{~Hz}, 4 \mathrm{H}), 7.73$ $(\mathrm{d}, J=10.7 \mathrm{~Hz}, 2 \mathrm{H}), 7.54(\mathrm{~s}, 2 \mathrm{H}), 3.52(\mathrm{~s}, 6 \mathrm{H}),-3.31(\mathrm{~s}, 2 \mathrm{H})$. UV-vis $\left(\mathrm{CH}_{2} \mathrm{Cl}_{2}\right): \lambda_{\max } / \mathrm{nm}(\log \varepsilon): 406$ (4.83), 500 (3.75), 535 (3.54), 573 (3.37), 627 (3.12). ESI-MS [M+H]+ $\left(\mathrm{CH}_{2} \mathrm{Cl}_{2}\right), \mathrm{m} / \mathrm{z}: 471.20405$; calculated for $\left[\mathrm{C}_{28} \mathrm{H}_{23} \mathrm{~N}_{8}\right]+: 471.20402$ (see $\mathrm{SI}$ ). 
5,15-Bis(1-methylimidazol-2-yl)porphyrinate zinc (II), (IP-2-Zn). IP-2-H (86 mg; $0.183 \mathrm{mmol})$ was dissolved in chloroform $(10 \mathrm{~mL})$. Separately, $\mathrm{Zn}\left(\mathrm{CH}_{3} \mathrm{CO}_{2}\right)_{2} \cdot 2 \mathrm{H}_{2} \mathrm{O}(401 \mathrm{mg} ; 1.83 \mathrm{mmol})$ was dissolved in methanol $(3 \mathrm{~mL})$ and added to the previously solution at $50{ }^{\circ} \mathrm{C}$, under stirring. The complexation was monitored by UV-vis and thin-layer chromatography (TLC). Once the reaction was completed, the solvent was removed and the solid dissolved in dichloromethane and washed with water. The organic layer was dried using anhydrous sodium sulfate and the solvent was removed. The solid was dried under vacuum, yielding $70 \mathrm{mg}$ of IP-2-Zn (81\% yield). ${ }^{1} \mathrm{H}$ NMR (400 MHz, DMSO, $\left.25^{\circ} \mathrm{C}\right): \delta$ mixture of atropoisomers $(\mathrm{ppm}) 10.38(\mathrm{~d}, J=3.8 \mathrm{~Hz}, 2 \mathrm{H}), 9.66(\mathrm{~d}, J=4.1 \mathrm{~Hz}, 4 \mathrm{H}), 9.04(\mathrm{~d}$, $J=4.3 \mathrm{~Hz}, 2 \mathrm{H}), 8.94(\mathrm{~d}, J=4.6 \mathrm{~Hz}, 2 \mathrm{H}), 8.02(\mathrm{~s}, 2 \mathrm{H}), 7.62(\mathrm{~s}, 2 \mathrm{H}) . \mathrm{UV}$-vis $(\mathrm{DMSO}): \lambda_{\max } / \mathrm{nm}(\log \varepsilon)$ : 415 (4.29), 545 (3.14), 581 (2.94) (see SI).

Note 1: The protons of CH3-N are hidden by water peak in DMSO. The low resolution of the spectra is due to solubility constraints and aggregation.

\section{5,15-Bis(1,3-dimethylimidazol-2-yl)porphyrinate zinc (II) diiodide, (IP-2-Zn+). The} quaternization of imidazolyl groups of IP-2-Zn $(20 \mathrm{mg}, 0.0375 \mathrm{mmol})$ was achieved via quaternization of nitrogen atoms with a large excess of iodomethane $(0.233 \mathrm{~mL}, 3.75 \mathrm{mmol})$ in $\mathrm{DMF}(0.15 \mathrm{~mL})$ at 30 ${ }^{\circ} \mathrm{C}$ for 24 hours. The progress of the reaction was followed by TLC. The product IP-2-Zn+ was precipitated with diethyl ether and, after filtration, it was obtained in almost quantitative yields. ${ }^{1} \mathrm{H}$ NMR (400 MHz, DMSO-D $\left.{ }^{6}, 25^{\circ} \mathrm{C}\right): \delta(\mathrm{ppm}) 10.73$ (s, 2H), $9.81(\mathrm{~d}, J=4.5 \mathrm{~Hz}, 4 \mathrm{H}), 9.07$ (d, $J=4.5$ $\mathrm{Hz}, 4 \mathrm{H}), 8.50$ (s, 4H), 3.70 (s, 12H). UV-vis $\left(\mathrm{H}_{2} \mathrm{O}\right): \lambda_{\max } / \mathrm{nm}(\log \varepsilon): 406$ (4.37), 540 (3.09), 573 (3.34). ESI-MS [M-I]+ (MeOH), m/z: 689.06134; calculated for $\left[\mathrm{C}_{30} \mathrm{H}_{26} \mathrm{IN}_{8} \mathrm{Zn}\right]+: 689.06111$ (see SI).

Bacteria. The experiments were performed with standard bacteria strains from American Type Culture Collection (ATCC) usually used as controls for antibiotic susceptibility testing. The bacteria used were: E. coli ATCC 25922, P. aeruginosa ATCC 27853 and S. aureus ATCC 29213. Further assays were performed with clinical resistant strains from the University of Coimbra Hospital Center, namely: two S. aureus methicillin-resistant (MRSA) strains, Sa1CHUC and Sa2CHUC, resistant to all beta-lactamic antibiotics, and the latter also resistant to quinolones; A. baumannii 141HUC highly resistant to all beta-lactamics, including carbapenems, quinolones, gentamicin and netilmicin; E. coli 189 resistant to all beta-lactamic antibiotics and to colistin (it produces the extended spectrum beta-lactamase CTXM-15, the penicillinase TEM-1, and the MCR-1 protein associated with colistin resistance); and $K$. pneumoniae $(K p)$ resistant to beta-lactam antibiotics, aminoglycosides and quinolones (it produces a carbapenemase OXA-181 and the extended spectrum beta-lactamase SHV-11). ${ }^{50}$ For biofilms studies, 
we used S. aureus ATCC 25925. The bacteria were cultured in Brain Heart Infusion (BHI) (Kasvi (R), Brazil).

Photoinactivation of planktonic bacteria. The planktonic bacteria cells were cultured in Mueller Hinton (MH) agar (Sigma Aldrich) at $37{ }^{\circ} \mathrm{C}$ overnight. Cell density was adjusted to the $0.5 \mathrm{McFarland}$ standard in sterile water, which corresponds to approximately $1.5 \times 10^{8} \mathrm{CFU} / \mathrm{mL}$. For PDT experiments, bacteria suspensions in sterile water were added to 96-well plates and incubated in the dark for $60 \mathrm{~min}$, at room temperature, with various photosensitizers concentrations. This incubation time was selected after preliminary experiments shown in Figure 8. It is interesting to see that after 45 min of incubation the surviving faction of CFU changes rather suddenly. This may be related to the displacement of native $\mathrm{Ca}^{+2}$ and $\mathrm{Mg}^{2+}$ cations and consequent critical destabilization of the outer membrane. At the end of the incubation time the plates were illuminated with a blue light LED (415 nm, $4 \mathrm{~mW} \mathrm{~cm} \mathrm{~cm}^{-2}$. The actual light dose absorbed by each compound was corrected by LED light emission overlap with compound absorption using the following multiplicative factors IP-4-H+= $2 * 0.81=1.62 \mathrm{~J} \mathrm{~cm}^{-2}, \mathbf{I P - 4}-\mathbf{Z n} \mathbf{n}=$ $2 * 0.68=1.36 \mathrm{~J} \mathrm{~cm}^{-2}$ and IP-2-Zn $+=2 * 0.54=1.08 \mathrm{~J} \mathrm{~cm}^{-2}$, where $2 \mathrm{~J} \mathrm{~cm}^{-2}$ is the nominal light dose of the LED light. ${ }^{51}$ Cells incubated with photosensitizers in the dark were covered with aluminum foil for the same time as the PDI groups (1 h). After illumination (or dark incubation) samples were shaken, diluted in PBS and mixed. Aliquots were taken from each well, streaked in MH agar in duplicate for CFU determination and incubated for $37{ }^{\circ} \mathrm{C} / 18-24 \mathrm{~h}$ in the dark. After $24 \mathrm{~h}$, the colonies were counted. The experiments were performed in triplicate. The statistical analysis was performed on GraphPad Prism 8 . 


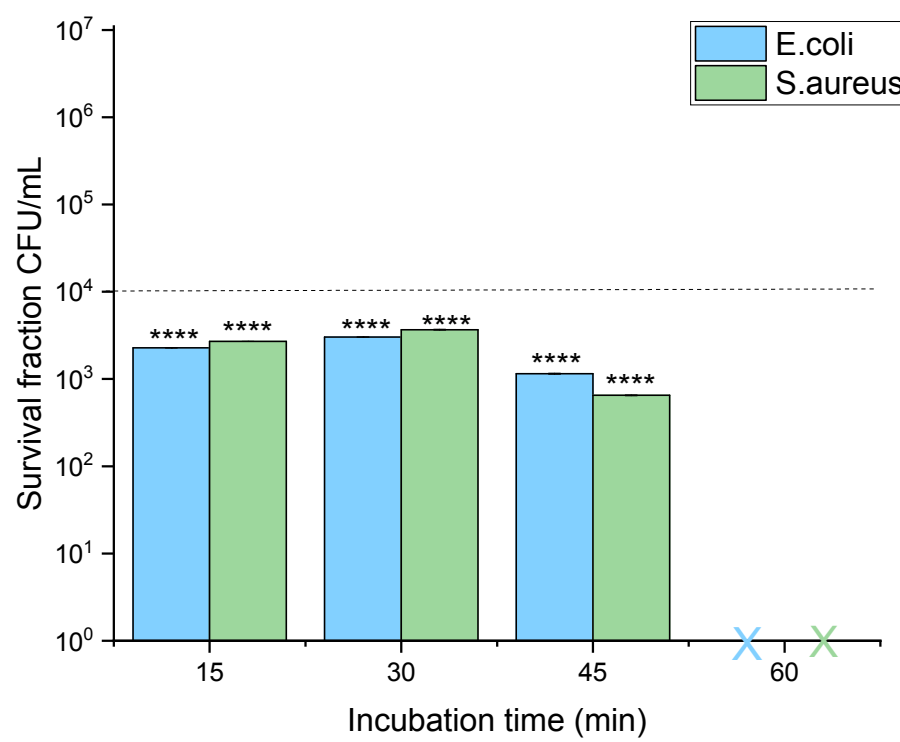

Figure 8. Optimization of incubation time with $1 \mu \mathrm{M}$ of IP-4-Zn+ and a nominal light dose of $2 \mathrm{~J} \mathrm{~cm} \mathrm{~cm}^{-2}$ at $415 \mathrm{~nm}$. The dashed black line shows viability values for 99.9\% (3 logs) inactivation of microorganisms and the cross a total inactivation $(7 \log )$. The data expressed as mean value $(n=3) \pm$ sem. The label $(* * * *)$ represents statistically significant difference $(\mathrm{p}<0.0001)$.

Biofilm growth. For biofilm growth, overnight cultures of $S$. aureus diluted at 1:9 in BHI were used. The microorganism was centrifuged (1500 rpm, $10 \mathrm{~min}$ ) and washed twice with PBS. Aliquots of the diluted bacterial suspensions were inoculated into 24-well flat-bottom sterile polystyrene microplates and incubated for $24 \mathrm{~h}$ at $37^{\circ} \mathrm{C}$.

Biofilm confocal microscopy. After 24 hours, the plates were observed under confocal microscopy and biofilm formation with a mean thickness of $20 \mu \mathrm{m}$ was confirmed. Then, $1 \mu \mathrm{M}$ solutions of compounds IP-4-Zn+ and IP-2-Zn+ were added to independent plates and the fluorescence intensity within the biofilm was followed over the incubation time of each compound $(30 \mathrm{~min}$ and $1 \mathrm{~h}$ for the photosensitizers, IP-4-Zn+ and IP-2-Zn+, respectively).

Photodynamic inactivation of biofilms. For PDI experiments the previous prepared plates with biofilms were incubated with various concentrations of the photosensitizers $(0.0052-1 \mu \mathrm{M})$ for $30-60$ min in the dark at room temperature. Wells used as controls were incubated with PBS only. After that, the plate was illuminated with a Biotable ${ }^{\circledR}$ emitting at $400-650 \mathrm{~nm}$, at $30 \mathrm{~mW} \mathrm{~cm}^{-2}$. Cells treated with photosensitizers in the dark were incubated covered with aluminum foil for the same time as the PDI 
groups ( $1 \mathrm{~h}$ ). Following irradiation (or dark incubation), porphyrins were carefully removed from the wells and the biofilms were washed once with PBS. The biofilms were scraped carefully, sonicated and then vortexed to homogenize the samples. Treated and untreated samples were serially diluted, plated on the $\mathrm{MH}$ petri dishes, and incubated for $24 \mathrm{~h}$ at $37^{\circ} \mathrm{C}$ in the dark to allow colony formation. After this time, the colonies were counted and CFU determined. The experiments were repeated nine times.

Human cell lines. HDFn neonatal human dermal fibroblast (Gibco - Thermal Fisher Scientific) and $\mathrm{HaCaT}$ immortalized human keratinocyte cell lines were employed to assess the cytotoxicity in the dark and the phototoxicity of the photosensitizers used in this study. Both types of cells were grown in DMEM (BioTech) with addition of 10\% fetal bovine serum (Cultilab - Campinas, SP, Brazil). Before the experiments, the cells were removed by trypsinization, washed with PBS and maintained in a humidified atmosphere at $37^{\circ} \mathrm{C}$ and $5 \% \mathrm{CO}_{2}$.

Cytotoxicity and phototoxicity in human cells. Toxicity towards human cell lines was evaluated in vitro using the 3-(4,5-dimethylthiazol-2-yl)-2,5-diphenyltetrazolium bromide (MTT, from Sigma Aldrich) assay to estimate the viability of cells after appropriate treatment. After cell attachment, photosensitizer solutions in PBS at concentrations between 0 to $10 \mu \mathrm{M}$ were added to the cell cultures and incubated for $30-60 \mathrm{~min}$ at $37^{\circ} \mathrm{C}$ in the dark. After illumination with the Biotable ${ }^{\circledR}$ to deliver 5 $\mathrm{J} / \mathrm{cm}^{2}$ in the wavelength range or after the equivalent time in the dark in control experiments, the cells were washed with fresh medium and plates were returned to the incubator for $24 \mathrm{~h}$. The MTT assay was performed $24 \mathrm{~h}$ after irradiation. MTT dissolved at $5 \mathrm{mg} / \mathrm{ml}$ in PBS was added to each well (final concentration $0.5 \mathrm{mg} / \mathrm{ml}$ ), and the microplates were further incubated for 3-4 hours. Medium were then discarded and $100 \mu \mathrm{l}$ of methanol were added to the cultures and mixed thoroughly to dissolve the dark blue crystals of formazan. Formazan quantification was performed using an automatic microplate reader (Multiskan Go Thermo) by absorbance measurements at $570 \mathrm{~nm}$. Each experiment was repeated three times. Data were expressed as mean absorbance value of six samples and standard error of the mean.

\section{ANCILLARY INFORMATION}

Supporting Information. 
Detailed experimental procedures and characterization of all compounds (RMN, UV-vis and mass); analytical procedures, supplementary computational data. Confocal microscopy of $S$. aureus biofilms along the incubation time (60 min) with $1 \mu \mathrm{M}$ of IP-4-Zn+ (video, avi). Confocal microscopy of $S$. aureus biofilms along the incubation time (30 min) with $1 \mu \mathrm{M}$ of IP-2-Zn+ (video, avi).

\section{ORCID}

Luis G Arnaut: 0000-0002-3223-4819

Mariette M. Pereira: 0000-0003-4958-7677

\section{Author Contributions}

CSV performed the synthesis, bacteria and multidrug-resistant bacteria studies, and prepared parts of the original draft. FS make the photochemical studies. AZ and KCB performed biofilm studies. NMI performed the studies with human cells. GJS led the studies with bacteria. SCCN and ACCP performed the calculations. VSB designed, prepared instrumentation and interpreted the data. LGA and MMP designed the research, interpreted the data and wrote the manuscript. All authors commented the manuscript.

\section{ACKNOWLEDGMENTS}

The authors thank FCT and QREN/FEDER for funding (UID/QUI/00313/2019, POCI-01-0145FEDER-027996), the NMR facility RECI/QEQ-QFI/0168/2012, and Prof. Francisco Guimarães for confocal microscopy. We acknowledge to Dr. Teresa Reis and Dr. Henrique Oliveira from the Unit of Clinical Pathology of CHUC for the kind gift of the multi-resistant strains. CSV thanks FCT for the PhD grant PD/BD/128317/2017 and AZ thanks Cnpq for the PhD grant 142578/2018-5.
ABBREVIATIONS
BHI
Brain heart infusion
CFU colony-forming units
CHUC University of Coimbra Hospital Center
DDQ 3-dichloro-5,6-dicyano-1,4-benzoquinone
DFT Density functional theory
DMF Dimethylformamide 


$\begin{array}{ll}\text { DMEM } & \text { Dulbecco's modified eagle medium } \\ \text { DMSO } & \text { Dimethyl sulfoxide } \\ \text { HOMO-LUMO } & \text { Highest occupied molecular orbital - lowest unoccupied molecular orbital } \\ \text { LED } & \text { Light-emitting diode } \\ \text { MBC } & \text { Minimum bactericidal concentrations } \\ \text { MH } & \text { Mueller Hinton } \\ \text { MSRA } & \text { Methicillin-resistant Staphylococcus aureus } \\ \text { MTT } & \text { 3-(4,5-Dimethylthiazol-2-yl)-2,5-diphenyltetrazolium bromide } \\ \text { PBS } & \text { Phosphate-buffered saline } \\ \text { PDI } & \text { photodynamic inactivation } \\ \text { ROS } & \text { Reactive oxygen species } \\ \text { TFA } & \text { Trifluoroacetic acid } \\ \text { TLC } & \text { Thin-layer chromatography } \\ \text { TMPyP } & \text { meso-Tetra( } N \text {-methyl-4-pyridyl)porphyrin }\end{array}$

\section{REFERENCES}

1. Laxminarayan, R.; Duse, A.; Wattal, C.; Zaidi, A. K. M.; Wertheim, H. F. L.; Sumpradit, N.; Vlieghe, E.; Hara, G. L.; Gould, I. M.; Goossens, H.; Greko, C.; So, A. D.; Bidfeli, M.; Tomson, G.; Woodhouse, W.; Ombaka, E.; Peralta, A. Q.; Qamar, F. N.; Mir, F.; Kariuki, S.; Bhutta, Z. A.; Coates, A.; Bergstrom, R.; Wright, G. D.; Brown, E. D.; Cars, O., Antibiotic resistance - the need for global solutions. Lancet Infect. Dis. 2013, 13, 1057-1098.

2. Ammerlaan, H. S. M.; Harbarth, S.; Buiting, A. G. M.; Crook, D. W.; Fitzpatrick, F.; Hanberger, H.; NHerwaldt, L. A.; van Keulen, P. H. J.; Kluytmans, J. A. J. W.; Kola, A., R. S.; Lingaas, E.; Meessen, N.; Morris-Downes, M. M.; Pottinger, J. M.; Rohner, P.; dos Santos, R. P.; Seifert, H.; Wisplinghoff, U.; Ziesing, S.; Walker, A. S.; Bonten, M. J. M., Secular trends in nosocolial bloodstrem infections: Antibiotic-resistant bacteria increase the total burden of infection. Clin. Infect. Dis. 2013, $56,798-805$.

3. Kumarasamy, K. K.; Toleman, M. A.; Walsh, T. R.; Bagaria, J.; Butt, F.; Balakrishnan, R.; Chaudhary, U.; Doumith, M.; Giske, C. G.; Irfan, S.; Krishnan, P.; Kumar, A. V.; Maharjan, S.; Mushtaq, S.; Noorie, T.; Paterson, D. L.; Pearson, A.; Perry, C.; Pike, R.; Rao, B.; Ray, U.; Sarma, J. B.; Sharma, M.; Sheridan, E.; Thirunarayan, M. A.; Turton, J.; Upadhyay, S.; Warner, M.; Welfare, W.; Livermore, D. M.; Woodford, N., Emergence of a new antibiotic resistance mechanism inIndia, Pakistan, and the UK: a molecular, biological, and epidemiological study. Lancet Infect. Dis. 2010, 10, 597-602. 
4. Stewart, P. S.; Costerton, J. W., Antibiotic resistance of bacteria in biofilms. Lancet 2001, 358, 135-138.

5. Paul, M.; Daikos, G. L.; Durante-Mangoni, E.; Yahav, D.; Carmeli, Y.; D., B. Y.; Skiada, A.; Andini, R.; Eliakim-Raz, N.; Nutman, A.; Zusman, O.; Antoniadou, A.; Pafundi, P. C.; Adler, A.; Dickenstein, Y.; Pavleas, I.; Zampino, R.; Daitch, V.; Bitterman, R.; Zayyad, H.; Koppel, F.; Levi, I.; Babich, T.; Friberg, L. E.; Mouton, J. W.; Theuretzbacher, U.; Leibovici, L., Colistin alone versus colistin plus meropenem for treatment of severe infections caused by carbapenem-resistant Gramnegative bacteria: an open-label, randomised controlled trial. Lancet Infect. Dis. 2018, 18, 391-400.

6. Carmeli, Y.; Armstrong, J.; Laud, P. J.; Newell, P.; Stone, G.; Wardman, A.; Gasink, L. B., Ceftazidime-avibactam or best available therapy in patients with ceftazidime-resistant Enterobacteriaceae and Pseudomonas aeruginosa complicated urinary tract infections or complicated intra-abdominal infections (REPRISE): a randomised, pathogen-directed, phase 3 study. Lancet Infect. Dis. 2016, 16, 661-673.

7. Costerton, J. W.; Stewart, F. A.; Greenberg, E. P., Bacterial biofilms: A common cause of persistent infections. Science 1999, 284, 1318-1322.

8. Hamblin, M. R.; Hasan, T., Photodynamic therapy: a new antimicrobial approach to infectious disease? Photochem. Photobiol. Sci. 2004, 3, 436-450.

9. Dabrowski, J. M.; Arnaut, L. G., Photodynamic Therapy (PDT) of Cancer: From a Local to a Systemic Treatment. Photochem. Photobiol. Sci. 2015, 14, 1765-1780.

10. Silva, E. F. F.; Serpa, C.; Dabrowski, J. M.; Monteiro, C. J. P.; Arnaut, L. G.; Formosinho, S. J.; Stochel, G.; Urbanska, K.; Simoes, S.; Pereira, M. M., Mechanisms of singlet oxygen and superoxide ion generation by porphyrins and bacteriochlorins. Chem. Eur. J. 2010, 16, 9273-9286.

11. Arnaut, L. G.; Pereira, M. M.; Dabrowski, J. M.; Silva, E. F.; Schaberle, F. A.; Abreu, A. R.; Rocha, L. B.; Barsan, M. M.; Urbanska, K.; Stochel, G.; Brett, C. M., Photodynamic therapy efficacy enhanced by dynamics: the role of charge transfer and photostability in the selection of photosensitizers. Chem. Eur. J. 2014, 20 (18), 5346-5357.

12. Morales-de-Echegaray, A. V.; Maltais, T. R.; Lin, L.; Younis, W.; Kadasala, N. R.; Seleem, M. N.; Wei, A., Rapid Uptake and Photodynamic Inactivation of Staphylococci by Ga(III)-Protoporphyrin IX. ACS Infect. Dis. 2018, 4, 1564-1573.

13. Hancock, R. E. W.; Farmer, S. W.; Li, Z.; Poole, K., Interaction of aminoglycosides with the outer membranes and purified lipopolysaccharide and OmpF porin of Escherichia coli. Antimicrob. Agents Chemother. 1991, 35, 1309-1314.

14. Merchat, M.; Bertolini, G.; Giacomini, P.; Villanueva, A.; Jori, G., Meso-substituted cationic porphyrins as efficient photosensitizers of Gram-positive and Gram-negative bateria. J. Photochem. Photobiol. B: Biol. 1996, 32, 153-157.

15. Jori, G.; Fabris, C.; Soncin, M.; Ferro, S.; Coppellotti, O.; Dei, D.; Fantetti, L.; Chiti, G.; Roncucci, G., Photodynamic therapy in the treatment of microbial infections: basic principles and perspective applications. Lasers Surg. Med. 2006, 38, 468-481.

16. George, S.; Hamblin, M. R.; Kishen, A., Uptake pathways of anionic and cationic photosensitizers into bacteria. Photochem. Photobiol. Sci. 2009, 8, 788-795.

17. Reddi, E.; Ceccon, M.; Valduga, G.; Jori, G.; Bommer, J. C.; Elisei, F.; Latterini, F.; Mazzucato, U., Photophysical properties and antibacterial activity of meso-substituted cationic porphyrins. Photochem. Photobiol. 2002, 75, 462-470.

18. Simões, C.; Gomes, M. C.; Neves, M. G. P. M. S.; Cunha, A.; Tomé, J. P. C.; Tome, A. C.; Cavaleiro, J. A. S.; Almeida, A.; Faustino, M. A. F., Photodynamic inactivation of Escherichia coli 
with cationic meso-tetraarylporphyrins - The charge number and charge distribution effects. Catal. Today 2016, 266, 197-204.

19. Skwor, T. A.; Klemm, S.; Zhang, H.; Schardt, B.; Blaszcyk, S.; Bork, M. A., Photodynamic inactivation of methicillin-resistant Staphylococcus aureus and Escherichia coli: A metalloporphyrin comparison. J. Photochem. Photobiol. B: Biol. 2016, 165, 51-57.

20. Matsumoto, J.; Yasuda, m., Optimal axial alkylpyridinium-bonded tricationic P-porphyrin in photodynamic inactivation of Escherichia coli. Med. Chem. Res. 2018, 27, 1478-1484.

21. Moura, N. M. M.; Esteves, M.; Vieira, C.; Rocha, G. M. S. R. O.; Faustino, M. A. F.; Almeida, A.; Cavaleiro, J. A. S.; Lodeiro, C.; Neves, M. G. P. M. S., Novel $\beta$-functionalized mono-charged porphyrinic derivatives: Synthesis and photoinactivation of Escherichia coli. Dyes Pigments 2019, 160, 361-371.

22. Wainwright, M.; Maisch, T.; Nonell, S.; Plaetzer, K.; Almeida, A.; Tegos, G. P.; Hamblin, M. R., Photoantimicrobials - are we afraid of the light? Lancet Infect. Dis. 2017, 17, e49-e55.

23. Eichner, A.; Gonzales, F. P.; Felgentrãger, A.; Regensburger, J.; Holzmann, T.; SchneiderBrachert, W.; Bäumler, W.; Maisch, T., Dirty hands: photodynamic killing of human pathogens like EHEC, MRSA and Candida within seconds. Photochem. Photobiol. Sci. 2013, 12, 135-147.

24. Huang, L.; Krayer, M.; Roubil, J. G. S.; Huang, Y.-Y.; Holten, D.; Lindsey, J. S.; Hamblin, M. R., Stable synthetic mono-substituted cationic bacteriochlorins mediate selective broad-spectrum photoinativation of drug-resistant pathogens at nanomolar concentrations. J. Photochem. Photobiol. B: Biol. 2014, 141, 119-127.

25. Silva, E. F. F.; Pedersen, B. W.; Breitenbach, T.; Toftegaard, R.; Kuimova, M. K.; Arnaut, L. G.; Ogilby, P. R., Irradiation- and Sensitizer-Dependent Changes in the Lifetime of Intracellular Singlet Oxygen Produced in a Photosensitized Process. J. Phys. Chem. B 2012, 116, 445-461.

26. Maisch, T.; Baier, J.; Franz, B.; Maier, M.; Landthaler, M.; Szeimies, R.-M.; Bäumler, W., The role of singlet oxygen and oxygen concentration in photodynamic inactivation of bacteria. Proc. Natl. Acad. Sci. USA 2007, 104, 7223-7228.

27. Valduga, G.; Breda, B.; Giacometti, G. M.; Jori, G.; Reddi, E., Photosensitization of wild and mutant strains of Escherichia coli by meso-tetra(N-methyl-4-pyridyl)porphine. Biochem. Biophys. Res. Commun. 1999, 256, 84-88.

28. Li, X.; Lee, D.; Huang, J.-D.; Yoon, J., Phthalocyanine-assembled nanodots as photosensitizers for highly efficient Type I photoreactions in photodynamic therapy. Angew. Chem. Int. Ed. 2018, 57, 9885-9890.

29. Aroso, R. T.; Calvete, M. J. F.; Pucelik, B.; Dubin, G.; Arnaut, L. G.; Dabrowski, J. M.; Pereira, M. M., Photoinactivation of microorganisms with sub-micromolar concentrations of imidazolium metallophthalocyanine salts. Eur. J. Med. Chem. 2019, 184, 111740.

30. Azenha, E. G.; Serra, A. C.; Pineiro, M.; Pereira, M. M.; Seixas de Melo, J.; Arnaut, L. G.; Formosinho, S. J.; Gonsalves, A. M. d. A. R., Heavy-atom effects on metalloporphyrins and polyhalogenated porphyrins. Chem. Phys 2002, 280, 177-190.

31. Tjahjono, D. H.; Akutsu, T.; Yoshioka, N.; Inoue, H., Cationic porphytins bearing diazolium rings: synthesis and their interacion with calf thymus DNA. Biochem. Biophys. Acta 1999, 1472, 333343.

32. Maximiano, R. V.; Piovesan, E.; Zílio, S. C.; Machado, A. E. H.; de Paula, R.; Cavaleiro, J. A. S.; Borissevitch, I. E.; Ito, A. S.; Gonçalves, P. J.; Neto, N. M. B., Excited-state absorption investigation of a cationic porphyrin derivative. J. Photochem. Photobiol. A: Chem. 2010, 214, 115-120. 
33. Machado, A. E. H.; Gomes, W. R.; Araújo, D. M. S.; Miglio, H. S.; Ueno, L. T.; de Paula, R.; Cavaleiro, J. A. S.; Neto, N. M. B., Synhesis and spectroscopic chracaterization of two tetrasubstituted cationic porphyrin derivatives. Molecules 2011, 16, 5807-5821.

34. Mroz, P.; Bhaumik, J.; Dogutan, D. K.; Aly, Z. K., Z.; Khalid, L.; Kee, H. L.; Bocian, D. F.; Holten, D.; Lindsey, J. S.; Hamblin, M. R., Imidazole metalloporphyrins as photosensitizers for photodynamic therapy: Role of molecular charge, central metal and hydroxyl radical production. Cancer Lett. 2009, 282, 63-76.

35. Gonsalves, A. M. d. A. R.; Varejão, J. M. T. B.; Pereira, M. M., Some new aspects related to the synthesis of meso-substituted porphyrins. J. Heterocycl. Chem. 1991, 28, 635-640.

36. Arsenault, G. P.; Bullock, E.; MacDonald, S. F., Pyrromethanes and Porphyrins Therefrom1. Journal of the American Chemical Society 1960, 82 (16), 4384-4389.

37. Silva, E. F. F.; Pimenta, F. M.; Pedersen, B. W.; Blaikie, F. H.; Bosio, G. N.; Breitenbach, T.; Westberg, M.; Breghøj, M.; Etzerodt, M.; Arnaut, L. G.; Ogilby, P. R., Intracellular singlet oxygen photosensitizers: on the road to solving the problems of sensitizer degradation, bleaching and relocalization. Integr. Biol. 2016, 8, 177-193.

38. Aroso, R. T.; Calvete, M. J. F.; Pucelik, B.; Dubin, G.; Arnaut, L. G.; Pereira, M. M.; Dabrowski, J. M., Photoinactivation of microorganisms with sub-micromolar concentrations of imidazolium metallophthalocyanine salts. Eur. J. Med. Chem. 2019, 184, 111740.

39. Mah, T.-F. C.; O'Toole, G. A., Mechanisms of biofilm resistance to antimicrobial agents. Trends Miocrobiol. 2001, 9, 34-39.

40. Cieplik, F.; Späth, A.; Regensburger, J.; Gollmer, A.; Tabenski, L.; Hiller, K.-A.; Bäumler, W.; Maisch, T.; Schmalz, G., Photodynamic biofilm inactivation by SAPYR - An exclusive singlet oxygen photosensitizer. Free Radic. Biol. Med. 2013, 65, 477-487.

41. Reimer L. G.; Stratton C. W.; Reller L. B., Minimum inhibitory and bactericidal concentrations of 44 antimicrobial agents against three standard control strains in broth with and without human serum. Antimicrob. Agents Chemother. 1981, 19, 1050-1055.

42. $\quad$ Becke, A. D., DFT. Phys. Rev. A 1988, 38, 3098-3100.

43. Becke, A. D., DFT. J. Chem. Phys. 1993, 98, 5648-5652.

44. Lee, C. T.; Yang, W. T.; Parr, R. G., LYP. Phys. Rev. B 1988, 37, 785-789.

45. Frisch, M. J.; Trucks, G. W.; Schlegel, H. B.; Scuseria, G.; Robb, M. A.; Cheeseman, J. R.; Scalmani, G.; Barone, V.; Mennucci, B.; Petersson, G. A.; Nakatsuji, H.; Caricato, M.; Li, X.; Hratchian, H. P.; Izmaylov, A. F.; Bloino, J.; Zheng, G.; Sonnenberg, J. L.; Hada, H.; Ehara, M.; Toyota, K.; Fukuda, R.; Hasegawa, J.; Ishida, M.; Nakajima, T.; Honda, Y.; Kitao, O.; Nakai, H.; Vreven, T.; Montgomery, J. A.; Peralta, J. E.; Ogliaro, F.; Bearpark, M.; Heyd, J. J.; Brothers, E.; Kudin, K. N.; Staroverov, V. N.; Kobayashi, R.; Normand, J.; Raghavachari, K.; Rendell, A.; Burant, J. C.; Iyengar, S. S.; Tomasi, J.; Cossi, M.; Rega, N.; Millam, J. M.; Klene, M.; Knox, J. E.; Cross, J. B.; Bakken, V.; Adamo, C.; Jaramillo, J.; Gomperts, R.; Stratmann, R. E.; Yazyev, O.; Austin, A. J.; Cammi, R.; Pomelli, C.; Ochterski, J. W.; Martin, R. L.; Morokuma, K.; Zakrzewski, V. G.; Voth, G. A.; Salvador, P.; Dannenberg, J. J.; Dapprich, S.; Daniels, A. D.; Farkas, O.; Foresman, J. B.; Ortiz, J. V.; Cioslowski, J.; Fox, D. J. Gaussian 09, Gaussian Inc.: Wallingford, CT, USA, 2009.

46. Schmidt, M. W.; Baldridge, K. K.; Boatz, J. A.; Elbert, S. T.; Gordon, M. S.; Jensen, J. H.; Koseki, S.; Matsunaga, N.; Nguyen, K. A.; Su, S.; Windus, T. L.; Dupuid, M.; Montgomery, J. A., Gamess. J. Comput. Chem. 1993, 14, 1347-1363.

47. Pettersen, E. F.; Goddard, T. D.; Huang, C. C.; Couch, G. S.; Greenblatt, D. M.; Meng, E. C.; Ferrin, T. E., UCSF Chimera--a visualization system for exploratory research and analysis. J. Comput. Chem. 2004, 25, 1605-1612. 
48. Sanner, M. F.; Olson, A. J.; Spehner, J. C., Reduced surface: an efficient way to compute molecular surfaces. Biopolymers 1996, 38, 305-320.

49. Monteiro, C. J. P.; Pereira, M. M.; Pinto, S. M. A.; Simões, A. V. C.; Sá, G. F. F.; Arnaut, L. G.; Formosinho, S. J.; Simões, S.; Wyatt, M. F., Synthesis of amphiphilic sulphonamide halogenated porphyrin:

Maldi-TOF mass spectra characterization and evaluation of 1-octanol/water partition coefficients. Tetrahedron 2008, 64, 5132-5138.

50. Da Silva, G. J.; Quinteira, S.; Bértolo, E.; Sousa, J. C.; Gallego, L. D., A.; Peixe, L., Long-term dissemination of an OXA-40 carbapenemase-producing Acinetobacter baumannii clone in the Iberian Peninsula. J. Antimicrob. Chemother. 2004, 54, 255-258.

51. Schaberle, F. A., Assessment of the actual light dose in photodynamic therapy. Photodiagnosis Photodyn. Ther. 2018, 23, 75-77. 


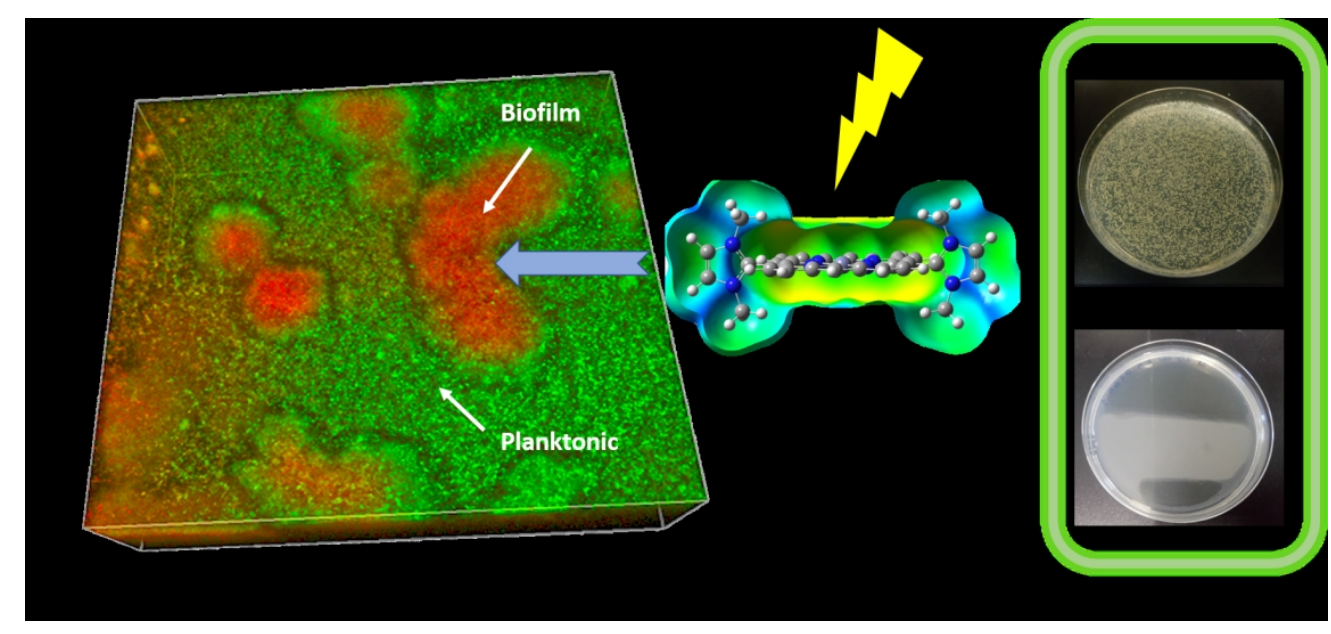

For Table of Contents Only

$305 \times 141 \mathrm{~mm}(150 \times 150 \mathrm{DPI})$ 